\title{
Rights Without Remedies: \\ Section 1983 Enforcement of Title IV-D of the Social Security Act
}

\author{
Ashish Prasad $\dagger$
}

Title IV-D of the Social Security Act ${ }^{1}$ mandates that states provide specific child support enforcement services in order to receive federal funding under the Aid to Families with Dependent Children (AFDC) program. ${ }^{2}$ Most states, however, have not carried out the mandate to locate absent fathers and collect child support payments from them. Out of approximately 9.4 million mothers living without their children's fathers in the spring of 1988, only fifty-one percent of these women had child support awards and only twenty-six percent had received their full child support the previous year. $^{3}$

This Comment argues for allowing mothers of children with absent fathers to bring suit under 42 USC § $1983^{4}$ to compel states to provide child support enforcement services under Title IV-D. ${ }^{5} \mathrm{~A}$

$\dagger$ A.B. 1989, University of Michigan; J.D. Candidate 1993, The University of Chicago.

142 USC $\$ \S 651-669$ (1988).

2 AFDC is a federal-state cooperative program intended to ensure that needy families with children deprived of parental support due to death, disability, or desertion receive welfare benefits. 42 USC $\$ \$ 601-617$ (1988). The program requires that "the State [have] in effect a plan approved under [Title IV-D] and operate [ ] a child support program in substantial compliance with such plan." 42 USC \& 602(a)(27).

${ }^{3}$ The State of America's Children 199127 (Children's Defense Fund, 1991).

- Section 1983 provides in relevant part:

Every person who, under color of any statute, ordinance, regulation, custom, or usage, of any State or Territory or the District of Columbia, subjects or causes to be subjected, any citizen of the United States or other person within the jurisdiction thereof to the deprivation of any rights, privileges, or immunities secured by the Constitution and laws, shall be liable to the party injured in an action at law, suit in equity, or other proper proceeding for redress.

42 USC § 1983 (1988).

- Only two appellate courts and five district courts have ruled on this issue. Four courts have denied the suits. Carelli $v$ Howser, 923 F2d 1208 (6th Cir 1991) (reversing the district court's denial of the defendant's motion to dismiss); Wehunt $v$ Ledbetter, 875 F2d 1558 (11th Cir 1989); Mason v Bradley, 789 F Supp 273 (N D Ill 1992); Oliphant v Bradley, 1992 US Dist LEXIS 8975 (N D Ill 1992). Three courts have permitted the suits. Behunin v Jefferson County Dept. of Social Services, 744 F Supp 255 (D Colo 1990); Beasley v Ginsberg, 1989 US Dist LEXIS 16682 (D Conn 1989); Howe v Ellenbecker, 774 F Supp 1224 (D SD 1991). See text accompanying notes 14-28. 
successful $\S 1983$ suit would result in a binding injunction upon the state to enforce Title IV-D or choose between judicial oversight of the state's child support enforcement program and loss of AFDC funds. ${ }^{6}$

A $\S 1983$ remedy is crucial in these cases because families have no other means of compelling the state to provide child support enforcement services. The only alternative would be an implied right of action under Title IV-D, ${ }^{7}$ but the Supreme Court has adopted a strong presumption against implied rights of action: the plaintiff must affirmatively demonstrate that Congress intended to allow a private right of action under the federal statute. ${ }^{8}$ Needy families with children probably could not meet this burden because the text and history of Title IV-D provide no explicit indication of congressional intent to create a private right of action. ${ }^{9}$

Section 1983, on its face, provides a cause of action for any violation of a federal statute. In Maine $v$ Thiboutot, ${ }^{10}$ the plaintiffs sued under $\S 1983$ claiming they were deprived of AFDC benefits due them under the Social Security Act. Rejecting the state's argument that $\S 1983$ be limited to civil rights or equal protection statutes, the Court held that $\S 1983$ may be triggered whenever a person acting under color of state law violates a federal statute. ${ }^{11}$ But the Court in Thiboutot did not elaborate a standard for determining, in the context of a specific statute, whether $\S 1983$ provides a

- See Rosado v Wyman, 397 US 397, 420 (1970) (remanding with instructions that the state have reasonable time either to conform Title IV-A program with AFDC funding conditions, or to choose to forego federal AFDC funding); Pennhurst State School \& Hospital $v$ Halderman, 451 US 1, 54 (1981) (White dissenting) ("If [the state prefers not to give up federal funding], it should propose a plan for achieving compliance, in which event, if it satisfied the court, a decree incorporating the plan could be entered and if the plan was unsatisfactory, the further use of federal funds could be enjoined.").

${ }^{2}$ See Cort $v$ Ash, 422 US 66, 78 (1975) (outlining four-factor inquiry for implied private right of action).

s Merrell Dow Pharmaceuticals, Inc. $v$ Thompson, 478 US 804, 812 n 9 (1986) (reviewing post-Cort cases that stress strict fidelity to congressional intent in implied right of action analysis).

The silence of the statute and legislative history on the question of a private right of action does not jeopardize the possibility of an action under $\S 1983$. Section 1983 enforcement is available unless the defendant-state actor demonstrates that Congress intended to disallow a private right of action. Wright $v$ Roanoke Redevelopment \& Housing Authority, 479 US 418, 423 (1987). See also Middlesex County Sewerage Authority v National Sea Clammers Ass'n, 453 US 1, 27 n 11 (1981) (Stevens concurring) ("[T]he burden is properly placed on the defendant to show that Congress, in enacting the particular substantive statute at issue, intended an exception to the general rule of $\S 1983 . ")$. Because $\S 1983$ is an express congressional authorization of private suits, its use does not raise the separation of powers concerns inherent in judicially created remedies.

10448 US 1 (1980),

11 Id at 6-8. 
cause of action. Since Thiboutot, the Court has allowed $\S 1983$ enforcement only if the statute meets two requirements. First, the statute must create "enforceable rights."12 Second, the statu'e must lack a "comprehensive remedial scheme."13

Section I of this Comment discusses how lower courts have approached the issue of $\S 1983$ enforcement of Title IV-D. Section II demonstrates that Title IV-D creates enforceable rights on behalf of needy families with children. Section III demonstrates that Title IV-D does not provide a comprehensive remedial scheme.

\section{Lower Court Approaches: WeHunt AND CARELLI}

In Wehunt $v$ Ledbetter ${ }^{14}$ mothers of children with absent fathers brought suit under $\S 1983$ against the Georgia Department of Health and Human Services for its failure to establish the paternity of their children and secure child support on their behalf. The Eleventh Circuit held that Title IV-D does not create enforceable rights on behalf of needy families with children because they are not the intended beneficiaries of the statute. ${ }^{15}$ The court reasoned that the primary purpose of Title IV-D was to recoup the state's welfare expenditures on behalf of needy families by collecting child support from absent parents. While the AFDC program itself was intended to benefit needy families with children, Title IV-D was intended to benefit the public treasury and taxpayers by reducing the present and future welfare rolls. ${ }^{16}$ The court pointed to the legislative history of Title IV-D:

The problem of welfare in the United States is, to a considerable extent, a problem of the non-support of children by their absent parents. Of the 11 million recipients who are now receiving [AFDC funds], 4 out of every 5 are on the rolls because they have been deprived of the support of a parent who has absented himself from the home.

The Committee believes that all children have the right to receive support from their fathers. The Committee bill, like the identical provision passed by the Senate (H.R. 3153) last

12 Suter v Artist M, $112 \mathrm{~S}$ Ct 1360, 1366 (1992); Wilder v Virginia Hospital Ass'n, 496 US 498, 508 (1990).

1s Sea Clammers, 453 US at 19-21; Wright, 479 US at 423.

14875 F2d 1558 (11th Cir 1989).

${ }^{15}$ Id at 1565-66.

1s Id at 1565 ("the goal of Title IV-D was to immediately lower the cost to the taxpayer as well as to lessen the number of families enrolling in welfare in the future-benefits to society as a whole rather than specific individuals"). 
year, is designed to help children attain this right, including the right to have their fathers identified so that support can be obtained. The immediate result will be a lower welfare cost to the taxpayer but, more importantly, as an effective support collection system is established fathers will be deterred from deserting their families to welfare and children will be spared the effects of family breakup. ${ }^{17}$

The court also pointed to the statutory provision requiring AFDC families to assign their child support rights to the state in return for AFDC aid - an indication that Congress intended to give states the ability to recoup welfare funds expended due to the delinquency of absent parents. ${ }^{18}$ Having decided that Title IV-D creates no enforceable rights for needy families because they are not the intended beneficiaries of the statute, the court found it unnecessary to determine whether the statute provides a comprehensive remedial scheme. ${ }^{19}$

Two years later, in Carelli $v$ Howser, ${ }^{20}$ the Sixth Circuit rejected a $\S 1983$ suit against the state of Ohio for its failure to locate absent parents, establish paternity, establish support obligations, and enforce existing support orders. After reviewing the legislative history of Title IV-D, the court rejected the Wehunt view and concluded that Congress intended to "protect both needy families with children and the public fisc." ${ }^{\text {21 }}$ "The court nonetheless rejected the $\S 1983$ remedy because it found that Title IV-D already provided a comprehensive remedial scheme. First, the court noted, Title IV-D and the implementing regulations issued by the Office of Child Support Enforcement establish an elaborate system for providing mandated services, recapturing funds, meeting performance indicators, and auditing state compliance. ${ }^{22}$ Second, the auditing system appeared to be working: the state was audited and assessed a penalty by the Secretary, which led to the institution of a new

${ }^{17}$ Id, quoting Social Services Amendments of 1974, S Rep No 93-1356, 93d Cong, 2d Sess 42 (1974).

${ }^{18}$ Id at 1565-66, referring to the requirements set out in Title IV-A of the Social Security Act, codified at 42 USC $\S 602$ (a)(26)(A) (1988).

19 Id at 1563. The dissent in Wehunt rejected the majority's view that enforceable rights were not created, and so went on to analyze the remedial scheme provided by Title IV-D. Judge Clark found the statute's remedial scheme insufficiently comprehensive to foreclose a $\S 1983$ action. Id at 1577 (Clark dissenting). For a description of the available remedies, see text accompanying notes $148-51$.

20923 F2d 1208, 1209 (6th Cir 1991).

${ }^{21}$ Id at 1211.

${ }^{22}$ Id at 1213-15, referring to $45 \mathrm{CFR} \S 305$ (1991). 
collective action program. ${ }^{23} \mathrm{~A}$ court order in this case would have duplicated the Secretary's efforts to bring the state plan into compliance, and the court concluded that Congress could not have intended such redundancy. ${ }^{24}$

The district courts that have considered these questions are also deeply divided. At least three district court judges have concluded, like the Sixth Circuit in Carelli, that Title IV-D creates enforceable rights, ${ }^{25}$ while two have concluded that it does not. ${ }^{26}$ Three of the district court opinions maintain, like the Wehunt dissent, that Title IV-D does not provide a comprehensive remedial scheme, ${ }^{27}$ while one holds that it does. ${ }^{28}$ The conflicting resolutions adopted by these various courts suggest that the current status of $\S 1983$ jurisprudence as it applies to Title IV-D needs clarification.

\section{Title IV-D Creates Enforceable Rights on Behalf of NeEdy Families With ChILdReN}

Section 1983 is only available for violations of federal statutes that create enforceable rights. The Supreme Court outlined the test for enforceable rights in Wilder $v$ Virginia Hospital Ass'n ${ }^{29}$ and Suter $v$ Artist $M{ }^{30}$ Part A of this Section examines this threepart test. Part B describes the statutory language and legislative history of Title IV-D. Part C shows that Title IV-D satisfies the Court's test for the creation of an enforceable right.

A. Requirements for Enforceable Rights Under Wilder and Artist $M$

In Wilder, the plaintiff was a nonprofit corporation of hospitals that sued under $\S 1983$ for violations of the Boren Amendment to the Medicaid Act. The Boren Amendment provides that a State plan for medical assistance must provide for payment

2s Id at 1215. The new program was to set time limits on responses to requests for service and establish priorities for providing service. Id.

24 Id at 1216.

25 Behunin v Jefferson County Dept. of Social Services, 744 F Supp 255, 258 (D Colo 1990); Howe v Ellenbecker, 774 F Supp 1224, 1230.(D SD 1991).

${ }^{28}$ Mason v Bradley, 789 F Supp 273, 277 (N D Ill 1992); Oliphant v Bradley, 1992 US Dist LEXIS 8975, *23 (N D Ill 1992).

${ }_{27}$ Beasley v. Ginsberg, 1989 US Dist LEXIS 16682 at *22 (D Conn 1989); Behunin, 744 F Supp at 257-58; Howe, 774 F Supp at 1230.

${ }_{28}$ Oliphant, 1992 US Dist LEXIS 8975 at *26-27.

20496 US 498, 508 (1990).

so 112 S Ct 1360, 1371 (1992). 
of the hospital services, nursing facility services, and services in an intermediate care facility for the mentally retarded ... through the use of rates ... which the State finds, and makes assurances satisfactory to the Secretary, are reasonable and adequate to meet the costs which must be incurred by efficiently and economically operated facilities. ${ }^{31}$

The Court concluded that the amendment grants health care providers enforceable rights to reimbursement rates that are reasonable and adequate. Writing for the majority, Justice Brennan asserted three primary grounds for this conclusion. First, health care providers are the intended beneficiaries of the Boren Amendment. ${ }^{32}$ The Court focused on whether the statute provided benefits in fact to plaintiffs, and whether the language indicated an intent to do so: "[T] here can be little doubt that health care providers are the intended beneficiaries of the Boren Amendment. The provision establishes a system for reimbursement of providers and is phrased in terms benefitting health care providers." 33

Second, the Boren Amendment imposes a "binding obligation" on states to adopt rates of reimbursement that are reasonable and adequate. ${ }^{34}$ The Amendment would not be satisfied if the state made findings that its rates are "reasonable and adequate" and made assurances to that effect to the Secretary, but did not actually adopt such rates. The Court explicitly rejected that argument: "[Petitioner's] argument that the requirements of findings and assurances are procedural requirements only . . . would render . . . the entire reimbursement provision, essentially meaningless." 35

The Court employed a two-factor analysis to reach its conclusion that the Boren Amendment provided a binding obligation: (1) it is cast in mandatory rather than precatory terms, ${ }^{36}$ and (2) the receipt of federal funds is expressly conditioned on compliance with the Amendment (the Secretary is authorized to withhold

${ }^{31}$ Medicaid Act, 42 USC $\$ 1396 a(a)(13)(A)$ (1988).

${ }^{32}$ Wilder, 496 US at 509-10, quoting Golden State Transit Corp. $v$ Los Angeles, 493 US 103,106 (1989).

${ }^{33}$ Id at 510. The Court in Golden State suggested in dictum that a statute does not create enforceable rights if the benefit to the plaintiffs is merely incidental. 493 US at 109. Even if the Court were to adopt such an exception to the enforceable rights analysis it would not affect the determination of whether Title IV-D creates enforceable rights on behalf of needy families with children. See text accompanying notes 92-101.

${ }^{34}$ Wilder, 496 US at 512.

${ }^{35}$ Id at 513-14.

s6 Id at 512, citing 42 USC $\S 1396 a(a)(13)(A)$ (1987 Supp). 
funds for noncompliance). ${ }^{37}$ The Court reasoned that these factors distinguished the Boren Amendment from the Developmentally Disabled Assistance and Bill of Rights Act (DDABRA), ${ }^{38}$ which it had held did not create enforceable rights in Pennhurst State School and Hospital $v$ Halderman. ${ }^{39}$ Section 6010 of the DDABRA provided in part that:

Congress makes the following findings respecting the rights of persons with developmental disabilities:

(1) Persons with developmental disabilities have a right to appropriate treatment, services, and habilitation for such disabilities.

(2) The treatment, services and habilitation for a person with developmental disabilities should be designed to maximize the developmental potential of the person and should be provided in the setting that is least restrictive of the person's personal liberty..$^{40}$

The Court concluded that this provision was meant merely to assist or encourage states to improve care and treatment of the mentally retarded. ${ }^{41}$ The provision "is simply a general statement of 'findings' and, as such, is too thin a reed to support the [creation of] rights" ${ }^{42}$ and "[i]f funds cannot be terminated for a State's failure to comply with $\S 6010, \S 6010$ can hardly be considered a 'condition' of the grant of federal funds." ${ }^{43}$ For a statute to impose binding obligations, the Court reasoned, states must be provided clear notice that by accepting funds they are obligated to comply with the provisions of the DDABRA. ${ }^{44}$ The Wilder Court applied this test to the Boren Amendment, where the Secretary was authorized to withhold funds for noncompliance, ${ }^{45}$ and concluded that "a State is on notice that it cannot adopt any rates it chooses and that the requirement that it make 'findings' is not a mere formality." ${ }^{46}$

${ }^{37} \mathrm{Id}$, citing 42 USC $\S 1396 \mathrm{a}(\mathrm{a})(13)(\mathrm{A})$. Note that relevant statutory language includes 42 USC \& 1396a(a) and (a)(13).

ss 42 USC $\S \S 6000$ et seq (1988).

39 451 US 1, 15-27 (1981).

to 42 USC $\S 6010$ (1976), now codified as 42 USC $\$ 6009$ (1988, Supp 1990).

11451 US at 18.

12 Id at 19.

is Id at 23 .

14 Id at 17.

43496 US at 512, quoting 42 CFR $\S 430.35$ (c) (1989).

16 Id at 514. 
Third, the Wilder Court found the language of the Boren Amendment not too "vague and amorphous" to render the Amendment unenforceable by a court. ${ }^{47}$ "While there may be a range of reasonable rates, there certainly are some rates outside that range that no State could ever find to be reasonable and adequate under the Act. Although some knowledge of the hospital industry might be required to evaluate a State's findings with respect to the reasonableness of its rates, such an inquiry is well within the competence of the judiciary." 48

The majority in Artist $M$ also adopted an enforceable rights analysis, ${ }^{48}$ though slightly different from that found in Wilder. The plaintiffs were children who brought suit against the state for failure to make "reasonable efforts" to preserve and reunite families as required by the AACWA. The statute provides that:

In order for a State to be eligible for payments under this part, it shall have a plan approved by the Secretary which ... provides that, in each case, reasonable efforts will be made (A) prior to the placement of a child in foster care, to prevent or eliminate the need for removal of the child from his home, and (B) to make it possible for the child to return to his home..$^{\text {so }}$

The Court concluded that the reasonable efforts provision of the AACWA does not create enforceable rights on behalf of children. ${ }^{51}$

Writing for the Court, Justice Rehnquist concluded that states were given "a great deal of discretion" in complying with the statute, despite the fact that the language of the AACWA was

47 Id at 519.

18 Id at 519-20. Justice Blackmun elaborated on this "vague and amorphous" standard in his dissent in Artist $M .112 \mathrm{~S} \mathrm{Ct}$ at 1373-74 (Blackmun dissenting). He concluded that the Adoption Assistance and Child Welfare Act (AACWA), 42 USC $\S 870$ et seq (1988), which requires that the state make "reasonable efforts" to preserve and reunite families, 42 USC \& 671(a)(15), was within judicial competence to enforce because state efforts could in some circumstances be deemed to violate the statute.

There may be a "range" of "efforts" to prevent unnecessary removals or secure beneficial reunifications that are "reasonable." It may also be that a court, in reviewing a State's strategies of compliance with the "reasonable efforts" clause, would owe substantial deference to the State's choice of strategies. That does not mean, however, that no State's efforts could ever be deemed "unreasonable."

Artist $M, 112$ S Ct at 1374, citing Wilder, 496 US at 520. See also Golden State, 493 US at 106 (stating, but not explaining, that the plaintiff's interest must not be "too vague and amorphous" for the judiciary to enforce).

$1912 \mathrm{~S} \mathrm{Ct}$ at 1366-67.

so 42 USC \& $671(\mathrm{a})(15)$.

$8112 \mathrm{~S} \mathrm{Ct}$ at 1370. 
mandatory rather than precatory, and that the Secretary was authorized to withhold funds for noncompliance. ${ }^{32}$ In the Court's view, the AACWA only requires the state to have a plan approved by the Secretary and containing sixteen enumerated features; it does not require the state to actually obey particular provisions of the plan. ${ }^{.3}$ Justice Rehnquist noted three grounds for this conclusion. First, the AACWA and subsequent regulations were general and offered no guidance as to what would constitute "reasonable efforts" at compliance. ${ }^{54}$ The particular statutory provision at issue suggested only that such plan as there was had to apply to all political subdivisions of the state, not that it actually had to operate in a specific manner. ${ }^{55}$ States were thus not provided notice that "failure to do anything other than submit a plan with the requisite features, to be approved by the Secretary, is a further condition on the receipt of funds from the Federal Government." Court had found, by contrast, that the Boren Amendment and its attendant regulations elaborated specific factors for determining the method for calculating rates, so states were given the requisite notice for the imposition of a binding obligation. ${ }^{\mathrm{sz}}$

Second, in Artist $M$, Justice Rehnquist found that the legislative history of the AACWA revealed that Congress had confidence in the ability and competence of state courts to discharge their duties under the statute. ${ }^{58}$ Third, a grant of substantial discretion to the states would not render the "reasonable efforts" clause "a dead letter." The Secretary retains the authority to reduce or eliminate payments upon a finding that the state is not making "reasonable

32 Id at 1369.

ss Id. (1991).

s4 Id at 1368-69. See for example, 42 USC § 671(a)(15), (b); 45 CFR $\S 1356.21(d)(4)$

ss Id at 1368 ("This section states that the state plan shall "provid[e] that the plan shall be in effect in all political subdivisions of the State, and, if administered by them, be mandatory upon them.' But we think that 'in effect' is directed to the requirement that the plan apply to all political subdivisions of the State, and is not intended to otherwise modify the word "plan." ").

se Id at 1369.

s7 496 US at $512-14$.

ss The Senate Finance Committee Report stated that:

The committee is aware of allegations that the judicial determination requirement can become a mere pro forma exercise in paper shuffling to obtain Federal funding. While this could occur in some instances, the committee is unwilling to accept as a general proposition that the judiciaries of the States would so lightly treat a responsibility placed upon them by Federal statute for the protection of children.

Adoption Assistance and Child Welfare Act of 1979, S Rep No 96-336, 96th Cong, 1st Sess 16 (1979). 
efforts," for example, if it is not even complying with its own plan. ${ }^{59}$

Lower courts are divided over whether the analysis in Artist $M$ modifies or replaces the three-pronged analysis articulated in Wilder ${ }^{80}$ Given that the Court did not explicitly overrule Wilder, principles of legal interpretation would suggest that the cases should be harmonized so as to minimize the effect of Artist $M$ upon $\S 1983$ jurisprudence. ${ }^{61}$ The different results in Artist $M$ and Wilder can be explained by the fact that the statute in Wilder (the Boren Amendment) required the state to operate in compliance with its plan, while the statute in Artist $M$ (the AACWA) merely required the state to have a plan in place. Thus, the effect of Artist $M$ is to modify the "binding obligation" analysis from Wilder by adding another factor. In addition to looking for mandatory rather than precatory terms and assessing whether the receipt of federal funds is expressly conditioned on compliance, ${ }^{62}$ a court must now also examine whether the statute or regulations elaborate specific factors to guide states regarding compliance with the mandate before concluding that the statute places a binding obligation on the states. $^{63}$

Wilder and Artist $M$ thus require that inquiry into whether a federal statute creates enforceable rights focus primarily upon three issues: first, whether plaintiffs are the intended beneficiaries of the statute; second, whether the statute imposes binding obligations upon states; and third, whether the statute is too vague and

50 $112 \mathrm{~S} \mathrm{Ct}$ at 1368-9. The impact of the Secretary's power to audit state programs and cut off federal funding is explored more fully in the text accompanying notes 148-57.

${ }^{\circ 0}$ Compare Chan $v$ City of New York, 1992 US Dist LEXIS 8341 at *7 (S D NY) (applying Wilder framework "with the modifications suggested by [Artist M]" to the Housing and Community Development Act of 1974) with City of Chicago $v$ Smith, 1992 US Dist LEXIS 15068 at *8-9 (N D Ill) (rejecting Wilder analysis of Older Americans Act since "such readings do not survive" Artist $M$ ).

B1 See generally Cass R. Sunstein, After the Rights Revolution 170, 186-89 (Harvard, 1990).

${ }^{62}$ See text accompanying notes $36-37$.

63 For an example of the relevancy of regulations, see Artist $M, 112 \mathrm{~S} \mathrm{Ct}$ at 1369, citing 45 CFR $\S \S 1356.21$ (d)(4), 1357.15(e)(1) (1991) ("The regulations promulgated by the Secretary to enforce the Adoption Act do not evidence a view that $\S 671$ (a) places any requirement for state receipt of federal funds other than the requirement that the State submit a plan to be approved by the Secretary."). See also Chevron U.S.A., Inc. v Natural Resources Defense Council, Inc., 467 US 837 (1984) (reasonable agency interpretations entitled to judicial deference). It is unlikely that agency regulations are by themselves sufficient to create enforceable rights because Congressional intent has always been the linchpin of enforceable rights analysis. The Court has not yet ruled on this issue, but see Wright, 479 US at 438 ( $O$ 'Connor dissenting) ("Such a result, where determination of $\S 1983$ 'rights' has been unleashed from any connection to congressional intent, is troubling indeed."). 
amorphous to be enforced by the judiciary. The question that arises, then, is whether Title IV-D meets these requirements.

B. Title IV-D Provisions Relating to Creation of Enforceable Rights

Title IV-D requires that states pay child support collections to AFDC and non-AFDC families. In order to receive benefits, AFDC families must "assign [to] the State any rights to support from any other person such applicant may have" ${ }^{64}$ and "cooperate with the State (i) in establishing the paternity of a child born out of wedlock with respect to whom aid is claimed, and (ii) in obtaining support payments for such applicant ...."65 The purpose of the assignment provision is to "reimburse [state governments] for assistance payments to the family." The first fifty dollars of child support collected each month, however, is paid to the AFDC family, and does not affect the family's AFDC eligibility or otherwise decrease any amount payable to it as state assistance. ${ }^{67}$ If the state is able to collect support in excess of the family's AFDC grant, then it must treat the collection as family income and determine if the family has become ineligible for assistance payments. ${ }^{68} \mathrm{Fami}$ lies who are not on AFDC receive the entire amount of child support that the state collects. ${ }^{69}$

The legislative history of Title IV-D reveals that Congress intended to provide benefits to needy families with children. Congress enacted Title IV-D in 1974 for the purpose of

enforcing the support obligations owed by absent parents to their children and the spouse (or former spouse) with whom such children are living, locating absent parents, establishing paternity, obtaining child and spousal support, and assuring that assistance in obtaining support will be available under this part to all children (whether or not eligible for aid under [Title IV-A]) for whom such assistance is requested. ${ }^{70}$

Congress stated that: "all children have the right to receive support from their fathers . . . . [Title IV-D is] designed to help chil-

42 USC \$ 602(a)(26)(A) (1988).

es 42 USC $\$ 602(a)(26)(B)$. The applicant need not cooperate, however, if she can establish "good cause" for failing to do so. Id.

68 42 USC § 657(b)(2).

o7 42 USC $\S \S 602(a)(8)(A)(v i), 657(b)(1)$.

os 45 CFR \& 232.20(b)(1) (1991).

62 USC \& $657(\mathrm{~b})(4)(\mathrm{B})$.

7042 USC § 651. 
dren attain this right, including the right to have their fathers identified so that support can be obtained."71

A series of increasingly strict amendments over the past several decades demonstrates congressional concern with strengthening child support enforcement by states. In 1967 Congress added amendments requiring states to establish formal programs for child support recovery from deserting parents, with half the funding to be provided by the federal government. ${ }^{72}$ Amendments passed in 1984 require states to implement specific enforcement mechanisms in order to increase the effectiveness of state programs. ${ }^{73}$ Congress further strengthened enforcement mechanisms in the 1988 amendments to Title IV-D. ${ }^{74}$

The regulations promulgated by the Secretary of Health and Human Services pursuant to Title IV-D's mandate establish extremely specific requirements for state child support enforcement plans. For example, states must respond to requests for service within precise time limits. ${ }^{75} \mathrm{~A}$ state must apply these procedures in

71 Social Security Amendments of 1984, S Rep No 93-1356, 93d Cong, 2d Sess 42 (1974). Congress was concerned with strengthening state child support enforcement programs:

In view of the fact that most States have not implemented in a meaningful way the provisions of present law relating to the enforcement of child support and establishment of paternity, the Committee believes that new and stronger legislative action is required in this area which will create a mechanism to require compliance with the law."

Social Security Amendments of 1973, S Rep No 93-553, 93d Cong, 1st Sess 43 (1973).

${ }^{72}$ Social Security Act Amendment of 1967, 42 USC § 602(a)(17) (Supp 1968), repealed by the Social Services Amendments of 1974, § 6305(c)(8), Pub L No 93-647, 88 Stat 2337, 2360 (1975).

${ }^{73}$ Social Security Act Amendment of 1984, 42 USC $\$ \S 654(20), 666$ (a), (b) (1988). The amendment requires that state programs include wage withholding for the automatic recovery of child support and arrearages, posting of security or a bond, garnishments and voluntary wage assignments, liens on real or personal property, withholding from tax returns, and reporting of significant arrearages to credit agencies.

${ }^{34}$ Family Support Act of 1988, Pub L No 100-485, 102 Stat 2352 (1988). The Act contains amendments to Title IV-D requiring states to: provide mechanisms for facilitating the periodic updating of child support awards, 42 USC § 667(a) (1988); revise the system of immediate wage withholding, 42 USC § 666(b)(3) (Supp 1990); establish a commission on interstate enforcement of child support, 42 USC $\$ 666$ (1988); and establish an automated tracking and monitoring system, 42 USC $\S 654(24)$ (1988).

${ }^{75}$ See 42 USC \& 652(h) (1988). The regulations promulgated under the Act require states to: access all appropriate sources for locating an absent parent and ensure that location information is sufficient to take the next appropriate action in a case within seventyfive calendar days of determining that location is necessary, 45 CFR § 303.3(b)(3)(1991); establish an order for support or complete service of process necessary to commence proceedings to establish a support order within ninety calendar days of locating an absent parent or establishing paternity, $45 \mathrm{CFR}$ § 303.4(d); file for paternity establishment or complete service of process to establish paternity within ninety calendar days of locating the alleged 
at least seventy-five percent of cases reviewed by the Secretary to achieve substantial compliance with Title IV-D requirements. ${ }^{76}$ Lack of substantial compliance will lead to a loss of up to five percent of the state's federal funding. ${ }^{77}$

C. Title IV-D Creates Enforceable Rights on Behalf of Needy Families with Children

As this Comment has noted, the Wilder and Artist $M$ inquiry into enforceable rights focuses on three issues. ${ }^{78}$ First, whether plaintiffs are the intended beneficiaries of the statute-does the statute benefit the plaintiffs, and is it phrased in terms of benefitting them? Second, whether the statute imposes binding obligations upon states-is the statute cast in mandatory rather than precatory terms, and is the provision of federal funds expressly conditioned on compliance with the statute? After Artist $M$ this turns also on whether the statute and regulations provide specific guidance to states as to how such compliance may be achieved. Third, whether the statute is too vague and amorphous to be enforced by the judiciary-could state efforts ever be deemed to violate the statute? Analysis of Title IV-D produces affirmative answers to each of these inquiries.

1. Needy families with children are the intended beneficiaries of Title IV-D.

Needy families with children are the intended beneficiaries of Title IV-D because the statute provides them with specific benefits and is phrased in terms of benefitting them. ${ }^{79}$ First, Title IV-D provides needy families with monetary benefits. The state pays AFDC families the first fifty dollars of child support that it collects each month from absent parents, in addition to their AFDC grants. ${ }^{80}$ It pays non-AFDC families the full amount of such sup-

father, 45 CFR § 303.5(a)(1); establish paternity or exclude the alleged father within one year of the later of successful service of process or the child's reaching six months of age, 45 CFR § 303.5(a)(2); and take appropriate enforcement action within thirty calendar days of identification of a delinquency or support-related noncompliance, or location of an absent parent, 45 CFR § 303.6(c)(2).

${ }^{78} 45$ CFR $\S 305.20(d)(2)$.

7742 USC \& 603(h)(1).

78 See text accompanying notes $32-63$.

79 See Wilder, 496 US at 510 ("The [Boren Amendment] establishes a system for reimbursement of providers and is phrased in terms benefiting health care providers....") (emphasis added).

so 42 USC § 657(b)(1). 
port. ${ }^{81}$ Title IV-D also mandates an increase in federal matching funds from fifty to sixty-six percent of state administrative costs ${ }^{82}$ and thus allows states to provide more services to needy families with children. Second, Title IV-D provides the benefits of paternity determination. These benefits include establishment of a personal relationship with the parent, establishment of an economic relationship with the parent, increased access to family medical histories, inheritance rights, and eligibility for Social Security benefits. $^{83}$ These benefits are in keeping with Title IV-D's purpose of "assuring that assistance in obtaining support will be available under [Title IV-D] to all children."

Despite this evidence, the Eleventh Circuit in Wehunt concluded that needy families with children are not the intended beneficiaries of Title IV-D, and thus held that Title IV-D does not create enforceable rights on their behalf. ${ }^{85}$ The court argued that Congress intended Title IV-D to benefit the public treasury and society as a whole rather than needy families with children. ${ }^{86}$ This argument is inconsistent with the stated purposes of Title IV-D. The legislative history of Title IV-D strongly suggests that Congress intended to benefit both needy families with children and the public treasury:

A major focus in the child-support debate during the 98th Congress has been the underlying purpose and intent behind the child-support enforcement program. Some maintained that it should aim primarily at recovering AFDC expenses incurred because families without child support must rely on welfare. Others contended that this Federal program ought to be available as a service to all families in need of assistance in securing child support, regardless of whether they receive welfare or not. This conference agreement reflects the rationale stated in both House and Senate bills which reaffirms that the program should be available to all who need services. This is an important statement of our intent that the Federal Government should assist in the costs of putting into place a nationwide efficient and effective child-support enforcement sys-

81 42 USC $\S \S 602(a)(8)(A)(v i), 657(b)(4)(B)$.

${ }_{82} 42$ USC $\& 655(a)(2)(C)$.

8s Wehunt, 875 F2d at 1574 (Clark dissenting).

84 42 USC § 651 .

${ }^{85}$ See text accompanying notes 14-19.

8s Wehunt, 875 F2d at 1565 ("the goal of Title IV-D was to immediately lower the cost to the taxpayer as well as to lessen the number of families enrolling in welfare in the future-benefits to society as a whole rather than specific individuals") (emphasis added). 
tem that enables all children in need of support to receive timely and expedient assistance. ${ }^{87}$

The very language of the legislative history cited by the Wehunt court suggests that Title IV-D has two beneficiaries. ${ }^{88}$

The Sixth Circuit in Carelli examined this same legislative history and concluded that Congress intended Title IV-D to benefit both needy families with children and the public treasury: "We see no reason to conclude that the statute must be read to protect needy families with children to the exclusion of protecting the public fisc or vice versa. It seems eminently reasonable that Congress intended both purposes to be served." mentation of Title IV-D also supports the conclusion that it has two intended beneficiaries. Congress would not have provided benefits to non-AFDC families ${ }^{90}$ - who are not otherwise a drain on the public treasury-if it intended Title IV-D to benefit the public treasury exclusively. Similarly, Congress would not have provided that AFDC families who assign their support rights to the state receive the first fifty dollars of support collected each month on their behalf ${ }^{21}$ if it had intended Title IV-D to benefit the public treasury alone.

In response to the dual beneficiary theory, one could argue that needy families with children are not entitled to private relief because they are not the primary beneficiaries of Title IV-D. Six months after Wehunt, in Golden State Transit Corp $v$ City of Los Angeles, ${ }^{92}$ the Supreme Court held that the National Labor Relations Act (NLRA) ${ }^{93}$ creates an enforceable right on behalf of taxicab franchisees to exert economic pressure on a union during the collective bargaining process. The Court held that the city could not interfere with that right by conditioning renewal of the franchise on settlement of the pending labor dispute. ${ }^{94}$ The Court in dictum suggested one circumstance in which a statute would not create enforceable rights:

s7 130 Cong Rec 23040 (Aug 8, 1984) (statement of Rep. Conable).

ss See the court's quotation from legislative history, reproduced in the text accompanying note 17-especially the last sentence.

- 923 F2d at 1211.

30 42 USC $\S \S 602(a)(8)(A)(v i), 657(b)(4)(B)$.

9142 USC \$ 657(b)(1).

22493 US 103 (1989).

9s 29 USC $\$ \$ 151$ et seq (1988).

*4 493 US at 111 ("the Act protects certain rights of labor and management against governmental interference"). 
In the NLRA, Congress has not just "occupied the field" with legislation that is passed solely with the interests of the general public in mind. In such circumstances, when congressional pre-emption benefits particular parties only as an incident of the federal scheme of regulation, a private damages remedy under $\S 1983$ may not be available. ${ }^{95}$

This language from Golden State suggests that enforceable rights may exist only in a statute's primary beneficiaries and not in incidental ones. ${ }^{98}$ On this view, $\S 1983$ action would be unavailable to needy families if Title IV-D was primarily intended to benefit the public treasury and benefits to needy families with children arose incidentally..$^{97}$

This argument is not convincing because neither of the conditions elaborated in Golden State obtain in the:Title IV-D context. Title IV-D was not passed "solely with the interests of the general public in mind."98 At least one of the interests Congress had in mind in passing Title IV-D must have been that of needy families with children. ${ }^{99}$ Also, needy families with children are not benefitted "only as an incident to a federal scheme of regulation." 100 Rather, they reap economic and non-economic gains from specific statutory provisions. ${ }^{101}$ In the absence of these two conditions, it would be premature to conclude, without further elaboration by the Court, that needy families with children must be the "primary" beneficiaries in order to be intended beneficiaries of the statute.

Thus, the first factor for the creation of an enforceable right-an intent to benefit the class-is fulfilled. The next question that arises is whether Title IV-D meets the second requirement for enforceable rights: the imposition of binding obligations upon the states.

9s Id at 109.

98 Henry Paul Monaghan, Federal Statutory Review Under Section 1983 and the APA, 91 Colum L Rev 233, 248 (1991) ("may not" indicates that whether a plaintiff is categorized as an intended or an incidental beneficiary determines whether or not that plaintiff has a primary federal right, redressable under $\$ 1983$ ).

97 For similar reasoning in a pre-Golden State case, see Wehunt, 875 F2d at 1565 ("in enacting Title IV-D Congress was primarily concerned with collecting child support in order to reduce the welfare rolls").

os Golden State, 493 US at 109.

-o See text accompanying notes 79-91.

100 Golden State, 493 US at 109.

201 See text accompanying notes 80-83. 
2. Title IV-D imposes binding obligations upon states.

Title IV-D contains the three factors that the Supreme Court uses to determine whether a statute imposes binding obligations upon states. ${ }^{102}$ First, the statute is cast in mandatory rather than precatory terms. A "State plan for aid and services to needy families with children must ... provide that the State has in effect a plan approved under [Title IV-D] and operates a child support program in substantial compliance with such plan."103 The state plan for child and spousal support "must . . . provide that such State will undertake ... to establish the paternity of [the] child"104 and take certain specific measures to ensure effective collection and disbursement of child support. ${ }^{105}$

Second, the receipt of federal AFDC funds is expressly conditioned on compliance with Title IV-D. ${ }^{106}$ "[I]f a State's program operated under [Title IV-D] is found as a result of a review ... not to have complied substantially with the requirements of [Title IVD] ... the amounts otherwise payable to the State under this part . . . shall be reduced."107 The reductions range from one to five percent depending on whether the state has been found not in substantial compliance on previous occasions, and are suspended if the state implements a corrective action plan within an appropriate time period. ${ }^{108}$

While it is true that state participation in the AFDC program is voluntary-a state could elect to not comply with Title IV-D requirements simply by foregoing federal AFDC funding ${ }^{100}$ - the same is true of the Boren Amendment in Wilder and the DDABRA in Pennhurst. Both of these statutes concerned voluntary programs but the Court did not analyze either statute in those

102 See text accompanying notes 62-63.

10342 USC $\$ 602(a)(27)$ (emphasis added).

10442 USC \& 654(4)(A) (emphasis added).

108 The statute requires that states: notify families at least annually of the amount of child support collected on their behalf, 42 USC $\$$ 654(5); give families the first fifty dollars of child support collected each month, 42 USC $\S 657(\mathrm{~b})(1)$; pass laws creating specific remedial devices to ensure effective child support, 42 USC $\$ 666(a)(1)-(9)$; and comply with other requirements that the Secretary deems necessary to the establishment of an effective Title IV-D program, 42 USC $\S 654(13)$, such as the provision of support enforcement services within specified time frames, 45 CFR $\S 303.6(c)(2)$ (1991).

106 Wilder, 496 US at 512 (Boren Amendment imposes binding obligations upon states because provision of federal funds is expressly conditioned on compliance with Amendment).

10742 USC $\S 603(\mathrm{~h})(1)$.

${ }^{108} 42$ USC $\$ \S 603(\mathrm{~h})(1), 603(\mathrm{~h})(2)(\mathrm{A})$.

109 Oliphant $v$ Bradley, 1992 US Dist LEXIS 8975 at *23 (N D Ill 1992) ("states are not obligated to participate in the AFDC program at all"). 
terms. ${ }^{110}$ Instead, the Court looked to the mandatory language of the statute and the express conditioning of federal funds on compliance. ${ }^{111}$ Where these factors were present (as in Wilder) the Court concluded that the statute imposed a binding obligation, where they were not (as in Pennhurst) the Court found no such obligation. This reflects an assumption that states will not choose to forego federal funding and that the voluntary nature of state participation in the program does not render Title IV-D's obligations nonbinding. ${ }^{112}$

Third, Title IV-D's obligations are binding because the statute and regulations elaborate specific factors to guide states toward "substantial compliance" with the statutory requirements. ${ }^{113}$ The Secretary's regulations require that a state meet detailed audit criteria, employ the required procedures in seventy-five percent of the cases reviewed, ${ }^{114}$ and keep to precise time frames in the performance of various services. ${ }^{115}$ States are left with little or no discretion in deciding how to comply with Title IV-D. In this sense, Title IV-D more closely resembles the Boren Amendment in Wilder than the AACWA in Artist M. The Boren Amendment and its regulations elaborated factors for determining "reasonable and adequate" reimbursement rates, and the Court held that a binding obligation was created for states to adopt rates which actually were "reasonable and adequate." The AACWA and its regulations, by contrast, did not elaborate factors for determining what were "reasonable efforts" at compliance, and the Court held that compliance with the statute was left to the discretion of individual states. ${ }^{117}$

On the other hand, one could argue that Title IV-D's obligations are not binding because the statute requires only "substantial" compliance, defined by the Secretary as compliance in only seventy-five percent of the cases reviewed. If a state is free to ignore fully one quarter of those families entitled to services, this might suggest that it also has a fair amount of flexibility in the implementation of Title IV-D. Other provisions of the statute also

110 Wilder, 496 US at 502; Pennhurst, 451 US at 11.

11 See text accompanying notes $42-46$.

312 Compare Rosado v Wyman, 397 US 397, 420 (1970) (remanding suit to enforce compliance with Title IV-A by instructing state to comply with AFDC conditions or forego funding).

11342 USC \& 602(a)(27).

11445 CFR \& $305.20(d)$.

215 See note 75.

116496 US at 519 n 17, citing 42 USC \& 1396a(a)(13)(A) (1982, Supp 1987).

$112112 \mathrm{~S} \mathrm{Ct}$ at 1369. 
support this view. ${ }^{118}$ Title IV-D lacks any language mandating that a state actually achieve any of the statute's goals or even comply with its own plan in order to receive federal AFDC funding. The Court in Artist $M$ held that analogous language in the AACWA did not create enforceable rights on behalf of children. ${ }^{119}$

This argument is flawed on two grounds. First, substantial state flexibility in the implementation of child support programs contradicts the very purpose of Title IV-D. Title IV-D was enacted to address the problems of state non-compliance that had arisen under older, discretionary systems: "[N]ew and stronger legislative action is required in this area which will create a mechanism to require compliance with the law."120 Congress intended to provide actual services to needy families with children through Title IV-D; it did not intend merely to encourage states to provide services. "[O]ur intent [is] that the Federal Government should assist in the costs of putting into place a nationwide efficient and effective child-support enforcement system that enables all children in need of support to receive timely and expedient service."121 In the AACWA, by contrast, Congress expressed confidence in the ability and competence of states to perform their duties under the statute. This suggested to the Court in Artist $M$ that states retained discretion to decide on compliance mechanisms. ${ }^{122}$

Second, the requirement that the state operate in "substantial compliance" with Title IV-D $\mathrm{D}^{123}$ is rendered meaningless if the statute authorizes flexibility in the implementation of the child support enforcement program. If the statute requires only that the state have a child support enforcement program in place and places no restrictions on the implementation of the program, the Secretary cannot exercise the enforcement power which the statute so carefully grants. ${ }^{124}$ The state can always claim that it is in seventy-five percent compliance, because it is at least attempting to employ the required procedures in seventy-five percent of the cases reviewed; the Secretary's determination that the state must actu-

118 For example, a state must "undertake" to establish paternity and secure support, rather than simply "establish paternity" or "secure support." 42 USC § 654(4).

119 112 S Ct at 1370, citing 42 USC \& 671(a)(15) (1988).

$120 \mathrm{~S}$ Rep No $93-553$ at 43 (cited in note 71 ).

121130 Cong Rec 23040 (Aug 8, 1984) (statement of Rep. Conable) (emphasis added).

$122112 \mathrm{~S} \mathrm{Ct}$ at $1369 \mathrm{n} 15$.

12342 USC $\$ 602(\mathrm{a})(27)$.

12442 USC $\$ \S 603(h)(1), 652(a)(4)$. 
ally comply with the required procedures would itself not be sufficient to create a "binding obligation" upon states. ${ }^{125}$

Even assuming that the Secretary could enforce compliance, a state would always be able to argue that it was in compliance generally and that specific cases of noncompliance the Secretary might uncover were merely part of the excluded twenty-five percent. Congress would not simultaneously create an elaborate mechanism for child support enforcement and then add a provision which would eviscerate its own system of oversight."126 The "substantial compliance" provision is better read not as a desire to preserve state flexibility in complying with Title IV-D requirements, but rather as a congressional recognition that the Secretary's review of cases cannot be expected to be accurate one hundred percent of the time.

Title IV-D, therefore, imposes binding obligations on states: the statute is cast in mandatory rather than precatory terms, the provision of federal AFDC funds is expressly conditioned upon state compliance with Title IV-D, and Title IV-D and its regulations elaborate specific factors to provide guidance in how to comply with the statute. The next and final question in the enforceable rights analysis is whether Title IV-D is too vague and amorphous to be enforced by the judiciary.

3. Title IV-D is not too vague and amorphous to be enforced by the judiciary.

Title IV-D satisfies the vague and amorphous standard articulated in Wilder because a court could in some circumstances deem that state efforts violated the statute. Given the extensive and elaborate requirements articulated in Title IV-D and its attendant regulations, a court need only inquire whether the state is employing the required procedures to locate absent fathers, establish paternity, and collect child support within the specified time frames. ${ }^{127}$ If not, the court would conclude that state child support enforcement efforts were in violation of Title IV-D.

Title IV-D is even less vague and amorphous than the Boren Amendment provision that provides that states reimburse health care providers at rates "reasonable and adequate" to meet the

\footnotetext{
125 See note 63.

${ }^{126}$ See Wilder, 496 US at 514 (rejecting state argument that Boren Amendment does not create enforceable right to rates that actually are reasonable and adequate because such argument would render provision meaningless).

127 See notes 73-75.
} 
costs of an "efficiently and economically" operated facility. ${ }^{128}$ The Court in Wilder held that this language was not too vague and amorphous for judicial enforcement where the statute outlined three factors for choosing a method of determining rate reasonableness and adequacy. ${ }^{129}$ With its specific percentage requirements and detailed regulations, the "substantial compliance" provision in Title IV-D gives far greater guidance than the "reasonable and adequate" provision at issue in Wilder. ${ }^{130}$

Thus, since Title IV-D satisfies all three of the Supreme Court's requirements for the creation of an enforceable right, Title IV-D should be read as creating enforceable rights on behalf of needy families with children. However, one more hurdle remains: a $\S 1983$ action is available for federal statutory violations only if the statute itself does not provide a comprehensive remedial scheme. ${ }^{131}$

\section{Title IV-D Does Not Provide A Comprehensive Remedial SCHEME}

After Middlesex County Sewerage Authority v National Sea Clammers Ass' $n^{132}$ and Wright $v$ Roanoke Redevelopment \& Housing Authority ${ }^{133}$ two issues determine whether a federal statute provides a comprehensive remedial scheme: (1) whether the statute provides for private judicial remedies, and (2) whether the statute provides a procedure by which plaintiffs can address state failures to abide by statutory provisions. Where these factors are present, the Court regards the statutory remedies as exclusive and will not allow additional enforcement through $\S 1983$. The test ensures plaintiffs a remedy for violations of federal statutory rights. ${ }^{134}$ The presumption is that Congress would not deprive statutory beneficiaries of a means of redress (as provided by $\S 1983$ ) without providing for comparable remedies within the statute itself. $^{\text {.38 }}$

12342 USC § 1396a(a)(13)(A) (1988).

129496 US at $519 \& \mathrm{n} 17$.

130 45 CFR \& 305.20(d)(1)-(2) (1992).

181 See, for example, Smith v Robinson, 468 US 992, 1009-13 (1984) (section 1983 enforcement of Education of the Handicapped Act (EHA) not available because statute contains carefully tailored administrative and judicial enforcement mechanisms).

${ }^{132} 453$ US 1 (1981).

1ss 479 US 418 (1987).

${ }^{234}$ See Note, Comprehensive Remedies and Statutory Section 1983 Actions: Context as a Guide to Procedural Fairness, 67 Tex L Rev 627, 644-53 (1989) (reviewing cases suggesting importance of leaving plaintiffs with judicial remedies).

${ }^{235}$ See, for example, Smith, 468 US at 1011 (finding EHA remedial scheme to be comprehensive where it ensured "that each child's individual educational needs be worked out 
Part A of this Section examines the two-factor test in Sea Clammers and Wright for analyzing whether a statute has a comprehensive remedial scheme. Part B applies the Sea Clammers/ Wright analysis to Title IV-D and shows that neither factor suggesting a comprehensive remedial scheme is present.

\section{A. Sea Clammers and Wright}

In Sea Clammers, fishermen brought suit against federal, state, and local officials under the Federal Water Pollution Control Act (FWPCA) ${ }^{136}$ and the Marine Protection, Research, and Sanctuaries Act (MPRSA) ${ }^{\mathbf{1 3 7}}$ for their alleged failure to prevent discharges and ocean dumping of waste materials. The Court held that enforcement mechanisms in the acts were sufficiently comprehensive to reveal congressional intent to preclude an implied right of action. ${ }^{138}$ The acts contained provisions that granted government officials the authority to pursue civil and criminal penalties for violations, ${ }^{139}$ permitted any "interested person" to seek judicial review of certain administrative actions taken under the acts (within 90 days), ${ }^{140}$ and authorized citizens to sue for injunctions to enforce the acts. ${ }^{141}$ While the plaintiffs did not seek a $\S 1983$ remedy, the Court sua sponte addressed the issue and concluded that Congress intended the statutory remedies in the FWPCA and MPRSA to preclude use of $\S 1983$.

The Court turned the dictum of Sea Clammers into law six years later in Wright. Tenants of low income housing projects brought suit under $\S 1983$ for alleged overbilling for utilities, in violation of rent ceilings imposed by the Brooke Amendment to the Housing Act of $1937^{142}$ and the implementing regulations of the Department of Housing and Urban Development (HUD). ${ }^{143}$ Writing for the majority, Justice White concluded that the statute lacked a comprehensive remedial scheme on three grounds. First,

\footnotetext{
through a process that begins on the local level and includes ongoing parental involvement, detailed procedural safeguards, and a right to judicial review").

${ }^{136} 33$ USC $\S \S 1251$ et seq (1988).

${ }^{137} 33$ USC $\S 1401$ et seq (1988).

${ }^{138}$ Sea Clammers, 453 US at 15 ("In the absence of strong indicia of a contrary congressional intent, we are compelled to conclude that Congress provided precisely the remedies it considered appropriate.").

13933 USC \& 1319.

14033 USC \& 1369(b).

14133 USC $\S \S 1365(\mathrm{a}), 1415(\mathrm{~g})$.

14242 USC \$ 1437a.

${ }^{143}$ Wright, 479 US at $420 \mathrm{n} 3$, citing 24 CFR $\S 860.403$ (1982).
} 
the Brooke Amendment and Housing Act made no provision for private judicial remedies: ${ }^{144}$ the only remedial scheme provided within the statute was HUD's authority to conduct audits, enforce annual contribution contracts, and cut off federal funds from Public Housing Authorities (PHA). These mechanisms were thoroughly inadequate for HUD to oversee effectively the performance of over 3,000 local PHAs across the country. ${ }^{145}$ Second, the PHA grievance procedures for the resolution of tenant disputes did not provide any means for tenants to complain about alleged failures of PHAs to abide by their annual contribution contracts, the Brooke Amendment, or HUD regulations. ${ }^{146}$ There would thus be few occasions on which HUD would be motivated to sue individual PHAs for such contractual violations. Third, HUD had apparently expressed the view that tenants could bring private suits to challenge PHA calculations of utility allowances: the grievance procedure regulations stipulated that a decision terminating a grievance proceeding would not affect a tenant's right to seek "judicial review," and proposed HUD regulations that would have limited federal judicial review were not adopted. ${ }^{147}$

\section{B. Title IV-D Lacks a Comprehensive Remedial Scheme}

Title IV-D does not provide the sort of means of private judicial redress necessary to satisfy the comprehensive remedial scheme test articulated in Sea Clammers and Wright. Title IV-D requires that a participating state develop and implement a plan to provide enforcement services; the Secretary is required to approve the plan, ${ }^{148}$ conduct an audit of the program at least once every three years to determine if the actual operation of the program complies with Title IV-D, ${ }^{149}$ and (if there is not substantial compliance) reduce the state's AFDC funding by one to five per cent. ${ }^{150}$ The regulations also require that states locate absent parents, es-

\footnotetext{
144 Id at 427.

145 Id at 428-29.

148 Id at 426.

${ }^{247}$ Id at 426-27, citing 24 CFR $\S \S 966.57$ (c), 965.473(3) (1985), 49 Fed Reg 31402 (1984).

${ }^{148} 42$ USC $\S 652(a)(3)$.

14042 USC $\$ 652(a)(4)$.

${ }^{150} 42$ USC $\S 603(\mathrm{~h})(1)$. Funding reductions are suspended if : (1) the state submits a corrective action plan to achieve substantial compliance within a time period found to be appropriate by the Secretary, (2) the Secretary approves the plan, and (3) the Secretary finds that the plan is being fully implemented and the state is progressing according to the specified timetable to achieve substantial compliance. 42 USC $\S 603(h)(2)$.
} 
tablish paternity, and establish support orders within specific time frames. ${ }^{151}$

Absent from the statute, however, are such private judicial remedies as citizens' suits or judicial review of administrative procedures. Also absent is any procedure under which needy families might complain about state failures to abide by Title IV-D. Absent $\S 1983$ enforcement, the only remedy available to needy families with children for state violations of Title IV-D is a generally ineffectual complaint filed with the Secretary. Yet the Secretary's only enforcement tool is reduction of federal AFDC funding, and even that is available only after an audit and a finding of substantial noncompliance. ${ }^{152}$ This mechanism simply is not adequate to the Secretary's task of enforcing state compliance with Title IV-D, especially given the widespread failure of states to provide effective child support enforcement services. ${ }^{153}$ Without a $\S 1983$ remedy, needy families are left essentially without any means of securing state compliance with the provisions of Title IV-D. ${ }^{154}$

While the Secretary has not expressed a view as to whether needy families may bring private suits to enforce Title IV-D, the remedial scheme of Title IV-D is even less comprehensive than that of the Brooke Amendment, which the Court in Wright held did not foreclose $\S 1983$ enforcement. ${ }^{165}$ Under the Brooke Amendment, tenants were at least provided with grievance procedures for resolution of disputes arising out of PHA regulations, although these procedures did not extend to utility allowances, and HUD itself could sue PHAs to enforce the annual contribution contracts. ${ }^{156}$ There are no comparable procedures in Title IVD-needy families simply cannot voice complaints regarding the failure to enforce support obligations, and the Secretary is not authorized to sue state agencies for noncompliance with Title IV-D requirements. If the Brooke Amendment lacks a comprehensive re-

151 See note 75.

${ }^{132} 42$ USC § 603(h); 45 CFR § 305.20(d) (1992).

${ }^{163}$ See text accompanying note 3 .

184 Needy families with children may have a cause of action under the Administrative Procedure Act (APA) against the Secretary for failure to enforce timeframes for service established by Title IV-D implementing regulations. 5 USC §§ 701 et seq (1988). See, for example, Clarke v Securities Industry Ass'n, 479 US 388, 394-96 (1987) (standing under APA requires injury in fact and within zone of interests protected or regulated by statute). However, a successful APA action could at most produce a cut-off of federal AFDC funding; the Secretary cannot actually compel states to provide child support enforcement services.

sos Wright, 479 US at $427-28$.

$18 B$ Id. 
medial scheme, then the more inadequate provisions of Title IV-D must lack one too.

Notwithstanding these arguments, the Sixth Circuit in Carelli concluded that Title IV-D does provide a comprehensive remedial scheme, and thus held that needy families with children may not bring suit under $\S 1983$ to enforce Title IV-D. ${ }^{157}$ The Carelli argument is flawed because it misconstrues the analysis required by Sea Clammers and Wright. Instead of analyzing Title IV-D in terms of whether it provided private judicial remedies or complaint procedures for statutory violations, the court simply noted the highly complex nature of the auditing scheme and examined how "effective" the process was in practice: "[Were relief to be granted,] the court's order would address all the shortcomings the Secretary has already ordered corrected."158 The Sea Clammers/ Wright analysis, however, is concerned with the extent of the remedial scheme from the perspective of the statutory beneficiaries; it focuses on whether they are left without a means of redress for violations of federal statutes. ${ }^{159}$ While a more effective auditing process might ultimately lead to provision of more services to needy families with children, Sea Clammers and Wright do not suggest that a court examine whether granting private enforcement would further the efficient system-wide management of the Title IV-D program. ${ }^{160}$

Therefore, since Title IV-D does not provide for private judicial remedies or complaint procedures about state violations, the statute lacks a comprehensive remedial scheme. Since Title IV-D also creates enforceable rights on behalf of needy families with children, these plaintiffs must be granted the right to sue under $\S 1983$ for state violations of Title IV-D.

\section{CoNCLUSTON}

Without a § 1983 remedy, needy families with children are completely deprived of access to the federal courts to secure child support enforcement services granted them by Title IV-D. This result is deeply at odds with the Thiboutot presumption that $\S 1983$ is available for federal statutory violations and the line of cases applying the presumption to particular statutes. Wilder, Artist $M$, Sea Clammers, and Wright suggest that the $\S 1983$ remedy is

\footnotetext{
167 See text accompanying notes 20-24.

1ss Carelli, 923 F2d at 1216.

160 Note, 67 Tex L Rev at 645 (cited in note 134).

${ }^{200}$ See text accompanying notes $132-35$.
} 
available if the statute creates enforceable rights and itself lacks a comprehensive remedial scheme. Title IV-D meets both of these requirements. Permitting $\S 1983$ enforcement in these circumstances would be true to the Supreme Court's $\S 1983$ jurisprudence and would provide redress of these families' grievances through the injunction power of the federal courts. 